\title{
Analisis Unjuk Kerja Mekanis Konduktor ACCR Akibat Perubahan Arus Saluran
}

\author{
Suprihadi Prasetyono \\ Jurusan Teknik Elektro-Program Studi Teknik-Universitas Jember \\ Alamat kantor: J1. Slamet Riyadi 62 Jember 68111 Telp/Fak : 0331-484977 \\ Alamat Rumah: Perumahan Pondok Gede Permai Blok D no. 40 jember \\ Telp.085228123475, E-mail : Shabri_prasetyo@yahoo.com
}

\begin{abstract}
ABSTRAK
Saluran transmisi udara umumnya menggunakan konduktor jenis ACSR (Aluminium Conductor Alloy Reinforced) yang memiliki batas temperatur kerja yang diijinkan sebesar $90^{\circ} \mathrm{C}$. Mempertimbangkan peningkatan kebutuhan daya listrik yang semakin pesat akhir-akhir ini, maka usaha menambah kapasitas saluran transmisi dilakukan dengan membangun saluran transmisi baru, akan tetapi diperlukan biaya yang sangat tinggi. Dewasa ini telah dikembangkan konduktor ACCR (Aluminium Conductor Composite Reinforced). Keunggulan dari konduktor jenis ini adalah tahan terhadap panas sampai $240^{\circ} \mathrm{C}$, sehingga kemampuan hantar arusnya menjadi lebih tinggi dibandingkan konduktor ACSR. Penelitian ini bertujuan untuk mengetahui karakteristik perubahan arus saluran terhadap unjuk kerja mekanis konduktor ACCR yang meliputi tegangan tarik, panjang pemuluran dan andongan, sehingga diharapkan dari hasil penelitian ini akan berguna untuk membangun struktur konstruksi saluran transmisi yang sesuai dengan sifat konduktor ACCR. Hasil simulasi memperlihatkan, bahwa dengan mempertahankan ROW dan tower yang ada, penggunaan konduktor ACCR dapat meningkatkan kapasitas penyaluran sistem transmisi sekitar $100 \%$ dibanding konduktor ACSR.
\end{abstract}

Kata kunci: unjuk kerja mekanis, saluran transmisi, ACSR dan ACCR.

\begin{abstract}
Overhead transmission line generally use ACSR conductor type (Aluminium Conductor Alloy Reinforced), it has makimum temperature allowable is $90^{\circ} \mathrm{C}$. To take into consideration of electric demand increasing recently, then effort to expand of transmission line capacity with develop new transmission, however need the high cost. ACCR conductor (Aluminium Conductor Composite Reinforced) has been developed recently. The superiority of this conductor is resist to the heat until $240^{\circ} \mathrm{C}$, hence current carrying capacity higher than ACSR conductor. This research aimed to study load current leading to mechanical performance characteristic ACCR conductor included tension, length of elongation and sag of conductor, hence expected from this research will be useful to develop construction structure of transmission line appropriate to characteristic of ACCR conductor. Based on this research it can be concluded that application of ACCR conductor improves transmission line capacities by $100 \%$ on existing ROW and tower.
\end{abstract}

Keywords : Mechanical performance, Transmission line, ACSR and ACCR.

\section{PENDAHULUAN}

Listrik merupakan bentuk energi yang sangat cocok dan nyaman bagi manusia modern. Tanpa listrik, infrastruktur masyarakat sekarang tidak akan menyenangkan. Makin tinggi standar kehidupan manusia akan semakin meningkat pula kebutuhan energi listrik di seluruh dunia. Untuk mengimbangi meningkatnya kebutuhan energi listrik tersebut, usaha atas perencanaan dan pengembangan sistem listrik yang ada harus terus diupayakan. Perencanaan dan pengembangan penghantar sebagai salah satu komponen utama sistem transmisi saluran udara pada

Catatan: Diskusi untuk makalah ini diterima sebelum tanggal 1 Juni 2007. Diskusi yang layak muat akan diterbitkan pada Jurnal Teknik Elektro volume 7, nomor 1, September 2007. umumnya dititik beratkan pada peningkatan konduktivitas listrik, kekuatan mekanis dan pertimbangan biaya yang ekonomis. Akan tetapi akhir-akhir ini, ketika kebutuhan daya listrik semakin meningkat, keadaan lahan yang semakin terbatas serta biaya investasi yang tinggi, maka pemilihan konduktor lebih ditujukan pada peningkatan kemampuan hantar arus yang semakin besar. Untuk meningkatkan kemampuan hantar arus tersebut, maka penghantar yang digunakan harus dibuat dari bahan dengan karakteristik temperatur yang tinggi (thermal resistance).

Kawat penghantar yang biasa digunakan (konvensional) untuk saluran transmisi udara adalah kawat penghantar alumunium jenis ACSR (Aluminium Conductor Steel Reinforced) yaitu kawat berlilit dengan inti serat baja di tengah yang dikelilingi oleh lapisan-lapisan serat aluminium [1]. Konduktor 
jenis ini mempunyai sifat tahan panas yang terbatas walaupun konduktivitas listriknya tinggi, karena menggunakan bahan aluminium jenis EC grade sehingga tidak dapat memberikan peningkatan kemampuan hantar arus. Pada umumnya konduktor konvensional mempunyai batas temperatur yang diijinkan tidak melebihi $75^{\circ} \mathrm{C}$ pada pembebanan harian dan pada keadaan beban darurat boleh meningkat sampai $90^{\circ} \mathrm{C}[2]$.

Dewasa ini telah dikembangkan penghantar ACCR (Aluminium Conductor Composite Reinforced). Penghantar berlilit ini mempunyai inti serat paduan aluminium-matrik yang dikelilingi oleh serat aluminium dengan kandungan zirkonium. Aluminium dengan kandungan zirkonium mempunyai sifat konduktivitas dan ketahanan panas yang tinggi sedangkan paduan aluminium-matrik yang berada di tengah akan menghasilkan kekuatan tarik yang tinggi tetapi berat yang lebih ringan dan konduktivitas yang lebih baik dari pada baja. Penghantar ACCR dapat beroperasi secara kontinyu pada temperatur $210^{\circ} \mathrm{C}$ dan $240^{\circ} \mathrm{C}$ pada kondisi darurat, sehingga akan menaikkan kapasitas penyaluran dua sampai tiga kali lebih besar dari pada menggunakan penghantar konvensional [3].

Konduktor ACCR sangat berpeluang untuk menggantikan konduktor konvensional yang ada, konduktor ACCR dapat dipasang dengan cepat dan mudah menggantikan konduktor konvensional dengan ROW (Rights of way) yang tersedia dengan sedikit ataupun tanpa perubahan pada tower dan alatalat pendukung lainnya. Teknologi konduktor ACCR telah diakui oleh Research \& Development Magazine dalam penghargaan $R \& D 100$ Award dan oleh Minnesota High Tech Association dalam Tekne Award untuk bidang pengembangan inovasi teknologi [4]. Beberapa pemasangan konduktor ACCR telah dilakukan antara lain; Xcel Energy's pada sistem $115 \mathrm{kV}$ di Minneapolis untuk menaikkan kapasitas penyaluran menggantikan konduktor ACSR dengan clearence dan tower yang tetap, Hawaiian Electric di North Shore pulau Oahu pada sistem 46 $\mathrm{kV}$ untuk menaikkan kapasitas penyaluran dengan mengunakan $72 \%$ ROW yang ada, WAPA (Weatern Area Power Administration) di Fargo, North Dakota telah membangun sistem transmisi $230 \mathrm{kV}$ baru dengan menggunakan konduktor ACCR untuk kondisi lingkungan es dan angin yang berat [5].

Adapun fungsi utama jaringan transmisi saluran udara adalah sebagai media untuk menyalurkan daya listrik dari pusat pembangkit ke pusat beban. Di dalam menyalurkan energi listrik tersebut saluran transmisi udara ini terbentang dan beroperasi pada kondisi yang bermacam-macam sehingga harus dirancang sedemikian rupa sehingga saluran transmisi ini harus mempunyai unjuk kerja yang baik terhadap kekuatan mekanis maupun elektris.

Kriteria unjuk kerja mekanis penghantar adalah penghantar harus tahan terhadap perubahan temperatur akibat arus yang dilewatkan dan harus tahan terhadap segala gaya-gaya atau tekanan/tarikan yang ada padanya akibat pembebanan mekanik maupun elektrik. Arus yang diperbolehkan (allowable current) untuk saluran transmisi udara dibatasi oleh kenaikan suhu yang disebabkan oleh mengalirnya arus dalam saluran tersebut. Pemuluran (creep) dan andongan (sag) yang terjadi tidak boleh melebihi batas aman dari ruang dan jarak bebas minimum (Clearence). Dengan mengetahui pengaruh pembebanan arus saluran terhadap unjuk kerja mekanis konduktor ACCR yang meliputi tegangan tarik konduktor, andongan dan panjang pemuluran konduktor, diharapkan akan berguna dalam perencanaan dan pembangunan struktur konstruksi saluran transmisi udara yang sesuai dengan sifat dari konduktor ACCR.

\section{TINJAUAN PUSTAKA}

Penelitian mengenai unjuk kerja mekanis penghantar saluran transmisi udara telah banyak dilakukan antara lain, penelitian tentang pengaruh perubahan lingkungan dan kecepatan angin terhadap unjuk kerja mekanis saluran transmisi udara menggunakan konduktor konvensional menggunakan metode rulling span dilakukan oleh Seppa [6]. Hasil penelitiannya menunjukkan bahwa rating saluran transmisi dipengaruhi oleh temperatur lingkungan dan kecepatan angin.

Migiantoro melakukan penelitian terhadap konduktor TACSR, yaitu penghantar aluminium tahan panas (TAL) yang mampu dioperasikan sampai $150^{\circ} \mathrm{C}$. Hasil penelitian menunjukkan bahwa penggunaan konduktor TACSR meningkatkan kemampuan hantar arus sekitar $41,20 \%$ akan tetapi berpengaruh pada kenaikan andongan sekitar 16,44\%. [7]

Kemampuan hantar arus saluran transmisi merupakan fungsi elektris, mekanis dan termis dari konduktor dan alat-alat pendukungnya, demikian dipaparkan oleh Jakubiak dan Matusz [8]. Arus maksimum dari saluran dibatasi oleh penurunan kekuatan konduktor, andongan dan batas temperatur yang diperbolehkan dari alat-alat pendukungnya. 
Kebutuhan daya listrik di wilayah Amerika Utara meningkat pesat sehingga sering kali dilakukan pengoperasian saluran dengan beban lebih besar dibanding pada awalnya saluran dirancang. Oleh karena itu, studi tentang keamanan dan keandalan terhadap konduktor dan peralatan pendukungnya pada saluran transmisi udara akibat beroperasi pada temperatur yang lebih tinggi dari yang diperbolehkan dilakukan oleh Douglass dkk [9].

\section{KONDUKTOR ACCR}

Diawal abad 21 ini telah dikembangkan oleh $3 M$ Corporation (St.Paul, Minnesota, U.S.), penghantar ACCR (Aluminium Conductor Composite Reinforced). Penghantar berlilit ini mempunyai inti serat paduan aluminium-matrik yang dikelilingi oleh serat aluminium dengan kandungan zirkonium (Zr). Aluminium dengan kandungan zirkonium mempunyai sifat konduktivitas dan ketahanan panas (thermal resistance) yang tinggi sedangkan paduan aluminium-matrik yang berada ditengah akan menghasilkan kekuatan tarik yang tinggi tetapi lebih ringan dan konduktivitas yang lebih baik dari pada baja. Serat inti ini terdiri atas ribuan serat aluminium oksida (Nextel 3M's 650 ceramic) dengan diameter yang sangat kecil.

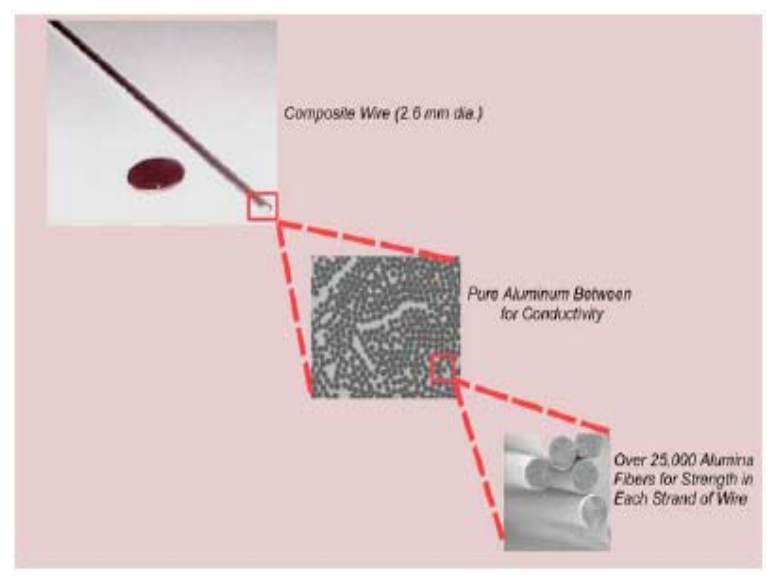

(a)

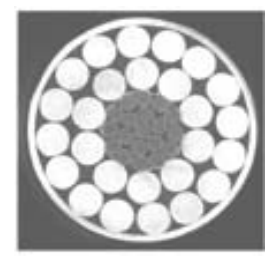

(b)

Gambar 1. Penghantar ACCR (Aluminium Conductor Composite Reinforced)

(a) Inti komposit aluminium oksida.

(b) Penampang penghantar ACCR dengan inti AlMatrik komposit dikelilingi serat Al-Zr.
Penerapan konduktor ini memiliki beberapa keuntungan antara lain [3]:

1. Penghantar ACCR dapat beroperasi secara kontinyu pada temperatur $210^{\circ} \mathrm{C}$ dan $240^{\circ} \mathrm{C}$ pada kondisi darurat, sehingga akan menaikan kapasitas penyaluran (ampacity) sistem transmisi dua sampai tiga kali lebih besar dari pada konduktor konvensional. ( berdasarkan validasi standart IEEE dan CALITEM ${ }^{\circledR}$ )

2. Memiliki karateristik mekanis yang sangat menguntungkan antara lain; tegangan tarik, berat dan diameter konduktor, sehingga memungkinkan pemasangan tanpa merubah ROW (rights of way) dan tower yang telah ada serta mengurangi waktu dan biaya pemasangan/pembangunan.

3. Tahan terhadap korosi karena secara keseluruhan terbuat dari bahan aluminium.

\section{Perhitungan Temperatur Konduktor}

Perhitungan kemampuan hantar arus pada saluran transmisi udara menurut IEEE Std.738 memenuhi persamaan keseimbangan panas, yaitu panas yang dibangkitkan oleh konduktor (panas rugi-rugi listrik + panas penyerapan matahari) sama dengan panas yang dilepaskan konduktor secara konveksi dan radiasi [10].

$$
\begin{aligned}
& \qquad W_{e}+W_{s}=W_{c}+W_{r} \\
& \text { Untuk, } \quad W_{e}=I^{2} R \text { (Watt/meter) } \\
& \text { dengan: } \\
& W_{e}=\text { rugi listrik } \\
& I=\text { Arus penghantar (A) } \\
& R=\text { Tahanan (Ohm/meter) }
\end{aligned}
$$

Panas yang diserap dari matahari $W_{s}$ diberikan oleh rumus:

dengan:

$$
W_{s}=\alpha \cdot E \cdot d(\text { Watt/meter })
$$

$\alpha=$ Koefisien serap matahari (1 untuk konduktor lama, 0,6 untuk konduktor baru)

$E=$ Intensitas radiasi matahari (1000-1500 Watt/ $\mathrm{m}^{2}$ )

$d=$ Diameter konduktor (meter)

Panas menyebar dari penghantar dengan cara radiasi dan konveksi.Panas yang disebarkan secara radiasi sesuai dengan hukum Stefan Boltzman yang menyatakan bahwa jumlah panas tersebar oleh radiasi berbanding pangkat empat dari suhu mutlak penghantar.

$$
W_{r}=17,9 \times 10^{-8} e\left(T_{c}^{4}-T_{a}^{4}\right) d
$$

dengan: 
$\sigma=$ konstanta Stefan Boltzman $\left(5,702 \times 10^{-8}\right.$ Watt $/ \mathrm{m}^{2}$ )

$e=$ emisivitas relatif permukaan konduktor yang bernilai antara 0,2-1,0 (untuk benda hitam $=1$ dan $\mathrm{Al}$ atau $\mathrm{Cu}=0,5$ )

$T_{c}=$ temperatur konduktor $\left({ }^{\circ} \mathrm{K}\right)$

$T_{a}=$ temperatur sekeliling (ambient temperature) $\left({ }^{\circ} \mathrm{K}\right)$

Penyebaran panas secara konveksi, hubungan umumnya adalah:

$$
W_{c}=18 . \Delta t \sqrt{p \cdot V_{m} \cdot d} \quad(\text { Watt } / \text { meter })
$$

dengan:

$p=$ tekanan udara (atm)

$V_{m}=$ kecepatan angin (m/detik)

$\Delta t=$ kenaikan temperatur $\left({ }^{\circ} \mathrm{C}\right)$

$d=$ diameter konduktor $(\mathrm{m})$

Sehingga persamaan (1) menjadi:

$I^{2} R+\alpha \cdot E \cdot d_{c}=18 \cdot \Delta t \cdot \sqrt{p \cdot V_{m} \cdot d}+17,9 \cdot 10^{-8} e\left(T_{c}^{4}-T_{a}^{4}\right) d_{c}$

Persamaan tersebut dapat digunakan untuk menentukan temperatur kerja konduktor sebagai akibat pembebanan arus saluran.

\section{Perhitungan Tegangan Tarik dan Andongan Konduktor}

Untuk menghitung tegangan tarik dan andongan pada kawat penghantar dapat diperoleh dari persamaan Catenary seperti dibawah ini [11]:

$$
\begin{gathered}
\sigma_{t 2}^{3}+A \sigma_{t 2}{ }^{2}=B \\
A=\frac{l^{2} \delta_{m}^{2}}{24{\sigma_{t 1}}^{2}} E+\alpha E\left(t_{2}-t_{1}\right)-\sigma_{t l} \\
B=\frac{l^{2} \delta_{m}{ }^{2} E}{24}
\end{gathered}
$$

dengan:
$l \quad=$ panjang kawat penghantar $(\mathrm{m})$
$\delta_{\mathrm{m}}=$ berat total spesifik kawat $\left(\mathrm{kg} \cdot \mathrm{m}^{-1} \cdot \mathrm{mm}^{-2}\right)$.
$\Delta \mathrm{t}=\mathrm{t}_{2}-\mathrm{t}_{1}=$ perubahan temperatur $\left({ }^{\circ} \mathrm{C}\right)$

Tegangan tarik yang terjadi tidak boleh melebihi tegangan tarik nominal kawat pada keadaan temperatur $\mathrm{t}_{1}$, sehingga,

$$
\sigma_{11}=\frac{T_{r}}{k \cdot q}
$$

dengan:

$$
\begin{aligned}
T_{r} & =\text { tegangan tarik nominal }(\mathrm{kg}) \\
\sigma_{t 1} & =\text { tegangan tarik spesifik awal }\left(\mathrm{kg} \cdot \mathrm{mm}^{-2}\right) \\
k & =\text { faktor keamanan }(2-5) \\
q & =\text { luas penampang penghantar }\left(\mathrm{mm}^{2}\right)
\end{aligned}
$$

Dengan demikian tegangan tarik horisontal pada temperatur $\mathrm{t}_{2}$ dapat dihitung sebagai berikut:

$$
T_{o t 2}=\sigma_{t 2} \cdot q
$$

Tegangan tarik pada temperatur $\mathrm{t}_{2}$ adalah:

$$
T_{t 2}=T_{o t 2}+\frac{l^{2} w^{2}}{8 T_{o t 2}}
$$

Panjang kawat penghantar pada temperatur $\mathrm{t}_{2}$ adalah:

$$
L_{t 2}=l+\frac{l^{3} w^{2}}{24 T_{o t 2}}
$$

Andongan pada temperatur $\mathrm{t}_{2}$ adalah:

$$
D_{t 2}=\frac{l^{2} w}{8 T_{o t 2}}
$$

dengan:

$L=$ lebar gawang (span) (m)

$D=$ andongan $(\mathrm{sag})(\mathrm{m})$

$w=$ berat konduktor per satuan panjang $\left(\mathrm{kg} \cdot \mathrm{m}^{-1}\right)$

$T=$ tegangan tarik konduktor $(\mathrm{kg})$

$T_{o}=$ tegangan tarik horisontal $(\mathrm{kg})$

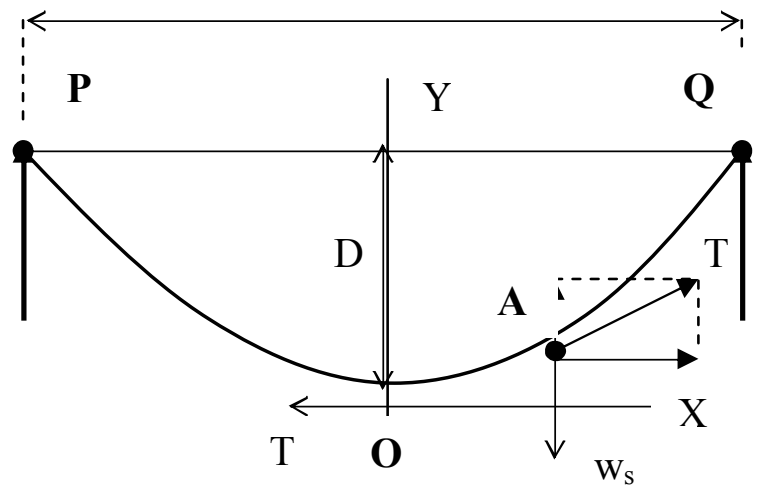

Gambar 2. Konduktor Dibentang pada Dua Tiang Penyangga

\section{Metode span ekivalen (Rulling Span)}

Metode rulling span diperkenalkan pertama kali oleh Thayer [12], adalah berguna untuk menghitung andongan dan tegangan tarik pada struktur dua dead end yang terdiri atas multi span yang berjarak tak sama. Jika ada $n$ span dengan panjang $L_{1}, L_{2}$, $L_{3}, L_{4}, \ldots \ldots ., L_{n}$ pada setiap bagian dan $L_{e}$ adalah ekuivalen span atau dinamakan rulling span pada setiap bagian. Panjang total dari jarak antar menara adalah:

$$
\begin{aligned}
& L_{e}=\left(L_{1}+L_{2}+L_{3}+L_{4}+\ldots \ldots . .+L_{n}\right) \\
& L_{e}=\sqrt{\left(\frac{L_{1}^{3}+L_{2}^{3}+L_{3}^{3}+\ldots \ldots \ldots \ldots+L_{n}{ }^{3}}{L_{1}+L_{2}+L_{3}+\ldots \ldots \ldots .+L_{n}}\right)}
\end{aligned}
$$




\section{Pengaruh Temperatur}

Panjang konduktor bergantung kepada perubahan temperatur konduktor, apabila temperatur konduktor meningkat maka akan menyebabkan pemuluran (creep) konduktor.

Misalkan:

$1_{0}=$ panjang kawat tidak ditegang pada ${ }^{0} \mathrm{C}$.

$l_{t}=$ panjang kawat tidak ditegang pada temperatur $\mathrm{t}^{0} \mathrm{C}$.

$\mathrm{L}_{\mathrm{o}}=$ panjang kawat ditegang pada ${ }^{0} \mathrm{C}$.

$\mathrm{L}_{\mathrm{t}}=$ panjang kawat ditegang pada $\mathrm{t}^{0} \mathrm{C}$.

$\alpha=$ koefisien muai panjang.

$\varepsilon_{\mathrm{t}}=$ perpanjangan ideal kawat karena tegangan pada $t^{0} \mathrm{C}$.

$\mathrm{E}=$ modulus elastisitas kawat.

$\mathrm{t}=$ temperatur kawat ${ }^{0} \mathrm{C}$.

$\sigma_{\mathrm{t}}=$ tegangan tarik spesifik kawat pada $\mathrm{t}^{0} \mathrm{C}$.

Maka, $\mathrm{lt}_{1}=\operatorname{lo}\left(1+\alpha \mathrm{t}_{1}\right)$ dan

$$
1 \mathrm{t}_{2}=\operatorname{lo}\left(1+\alpha \mathrm{t}_{2}\right)
$$

Perubahan panjang kawat karena perubahan temperatur,

$$
1 t_{2}-1 t_{1}=10 . \alpha\left(t_{2}-t_{1}\right)
$$

Perubahan temperatur akan menyebabkan perubahan tegangan (stress) dalam kawat sesuai dengan hukum Hooke,

$$
\begin{aligned}
\mathrm{Lt} & =\operatorname{lt}\left(1+\varepsilon_{\mathrm{t}}\right)=\operatorname{lt}\left(1+\sigma_{\mathrm{t}} \mathrm{E}\right) \\
& =\operatorname{lo}\left(1+\alpha_{\mathrm{t}}\right)\left(1+\sigma_{\mathrm{t}} \mathrm{E}\right)
\end{aligned}
$$

Perubahan kawat yang ditegang karena perubahan temperatur dari $t_{1}$ ke $_{2}$ adalah;

$$
\begin{aligned}
\mathrm{Lt}_{2}-\mathrm{Lt}_{1}= & \mathrm{lo}\left(1+\alpha \mathrm{t}_{2}\right)\left(1+\sigma_{\mathrm{t}} / \mathrm{E}\right)-\mathrm{lo}\left(1+\alpha \mathrm{t}_{1}\right)\left(1+\sigma_{\mathrm{t} 1} / \mathrm{E}\right) \\
\mathrm{Lt}_{2}-\mathrm{Lt}_{1}= & 1_{0}\left[\alpha\left(\mathrm{t}_{2}-\mathrm{t}_{1}\right)+\frac{1}{E}\left(\sigma_{\mathrm{t} 2}-\sigma_{\mathrm{t} 1}\right)+(\alpha / \mathrm{E})\left(\mathrm{t}_{2} \sigma_{\mathrm{t} 2}\right.\right. \\
& \left.\left.-\mathrm{t}_{1} \sigma_{\mathrm{t} 1}\right)\right]
\end{aligned}
$$

Suku baris kedua dari persamaan terakhir ini kecil sekali sehingga dapat diabaikan. Jadi secara pendekatan,

$$
\mathrm{Lt}_{2}-\mathrm{Lt}_{1}=\mathrm{1}_{0}\left[\alpha\left(\mathrm{t}_{2}-\mathrm{t}_{1}\right)+\frac{1}{E}\left(\sigma_{\mathrm{t} 2}-\sigma_{\mathrm{t}}\right)\right]
$$

\section{Pengaruh Tekanan Angin}

Tekanan angin akan mempengaruhi berat spesifik kawat. Berat sendiri kawat bekerja vertikal sedang tekanan angin dianggap seluruhnya bekerja horizontal. Jumlah vektoris kedua gaya ini menjadi berat total spesifik kawat. Tekanan angin dinyatakan oleh :

dengan:

$$
P=f \cdot p \cdot F
$$

$P=$ tekanan angin $(\mathrm{kg})$ $f=$ faktor bentuk.

$p=$ tekanan angin spesifik $\left(\mathrm{kg} / \mathrm{mm}^{2}\right)=v^{2} / 16$ $\mathrm{kg} / \mathrm{mm}^{2}$

$\mathrm{v}=$ kecepatan angin $(\mathrm{m} / \mathrm{dt})$

$F=$ Luas permukaan kawat yang tegak lurus arah angin $\left(\mathrm{m}^{2}\right)$

Karena tekanan angin tidak merata maka digunakan koefisien ketidaksamaan ( $\mathrm{d}=0.75 \mathrm{di}$ Indonesia), jadi:

$$
P=\text { f.d.p.F }
$$

dengan $\mathrm{p}$ bergantung dari tinggi kawat penghantar diatas permukaan tanah dan $\mathrm{f}$ bergantung dari diameter kawat penghantar.

Nilai dari $\mathrm{F}$ diambil = panjang kawat dikalikan dengan diameter kawat konduktor. Sehingga berat total spesifik kawat penghantar $\left(\mathrm{Kg} / \mathrm{m} / \mathrm{mm}^{2}\right)$ adalah sebagai berikut:

$$
\delta_{\mathrm{m}}=\sqrt{\delta^{2}+\delta_{w}^{2}}
$$

dengan:

$$
\begin{aligned}
\delta_{\mathrm{w}} & =\text { tekanan angin spesifik } \\
& =P / q\left(\mathrm{~kg} \cdot \mathrm{m}^{-1} \cdot \mathrm{mm}^{-2}\right) . \\
\delta & =\text { berat sendiri spesifik kawat } \\
& =W / q\left(\mathrm{~kg} \cdot \mathrm{m}^{-1} \cdot \mathrm{mm}^{-2}\right) . \\
\delta_{\mathrm{m}} & =\text { berat total spesifik kawat }\left(\mathrm{kg} \cdot \mathrm{m}^{-1} \cdot \mathrm{mm}^{-2}\right) .
\end{aligned}
$$

\section{METODOLOGI PENELITIAN}

Bahan penelitian

A. Dua buah konduktor dengan data spesifik sebagai berikut [3][13]:

\begin{tabular}{lll}
\hline Spesifikasi Konduktor & \multicolumn{1}{c}{ ACSR } & \multicolumn{1}{c}{ ACCR } \\
\hline 1. Diameter & $25,75 \mathrm{~mm}$ & $25,2 \mathrm{~mm}$ \\
2. Luas penampang & $392,80 \mathrm{~mm}^{2}$ & $374 \mathrm{~mm}^{2}$ \\
3. Berat Konduktor & $1300 \mathrm{~kg} / \mathrm{km}$ & $1067 \mathrm{~kg} / \mathrm{km}$ \\
4. Resistans DC $\left(20^{\circ} \mathrm{C}\right)$ & $0,0813 \mathrm{ohm} / \mathrm{km}$ & $0,0854 \mathrm{ohm} / \mathrm{km}$ \\
5. Tegangan tarik & $5,95 \mathrm{~kg} / \mathrm{mm}^{2}$ & $15,22 \mathrm{~kg} / \mathrm{mm}^{2}$ \\
$\quad$ spesifik initial & & \\
6. Modulus Elastisitas & $75,51 \mathrm{kN} / \mathrm{mm}^{2}$ & $77 \mathrm{kN} / \mathrm{mm}^{2}$ \\
7. Koef. Muai Panjang & $18,9.10^{-6} \rho \mathrm{C}$ & $16,6.10^{-6}{ }^{\circ} \mathrm{C}$ \\
8. Temp. operasi maks & $90^{\circ} \mathrm{C}$ & $240^{\circ} \mathrm{C}$ \\
\hline
\end{tabular}

B. Saluran udara tegangan ekstra tinggi (SUTET) $500 \mathrm{kV}$ jalur Paiton - Kediri yang memiliki struktur dua dead-end yaitu pada span nomer 47 sampai dengan 56 [8].

Alat yang digunakan:

Satu unit komputer pribadi dengan spesifikasi RAM 258MB dan mikroprosesor Pentium 4(R), 2.40 Ghz dan perangkat lunak (software) Matlab.7.0. 
Jalannya Penelitian

Tahapan dari pelaksanaan penelitian ini adalah sebagai berikut:

1. Melakukan simulasi dan perhitungan penggunaan penghantar ACSR pada saluran udara tegangan ekstra tinggi (SUTET) $500 \mathrm{kV}$ jalur PaitonKediri, dengan mengambil sampel tower yang memiliki struktur dua dead-end sebagai simulasi. Adapun parameter yang dihitung adalah temperatur, tegangan tarik, panjang kawat dan andongan penghantar, giagram alir program perhitungan dapat dilihat seperti gambar 3 .

2. Melakukan hal yang sama untuk penghantar ACCR.

3. Analisis terhadap hasil perhitungan dan membandingkan antara kedua penghantar.

4. Membuat kesimpulan hasil penelitian.

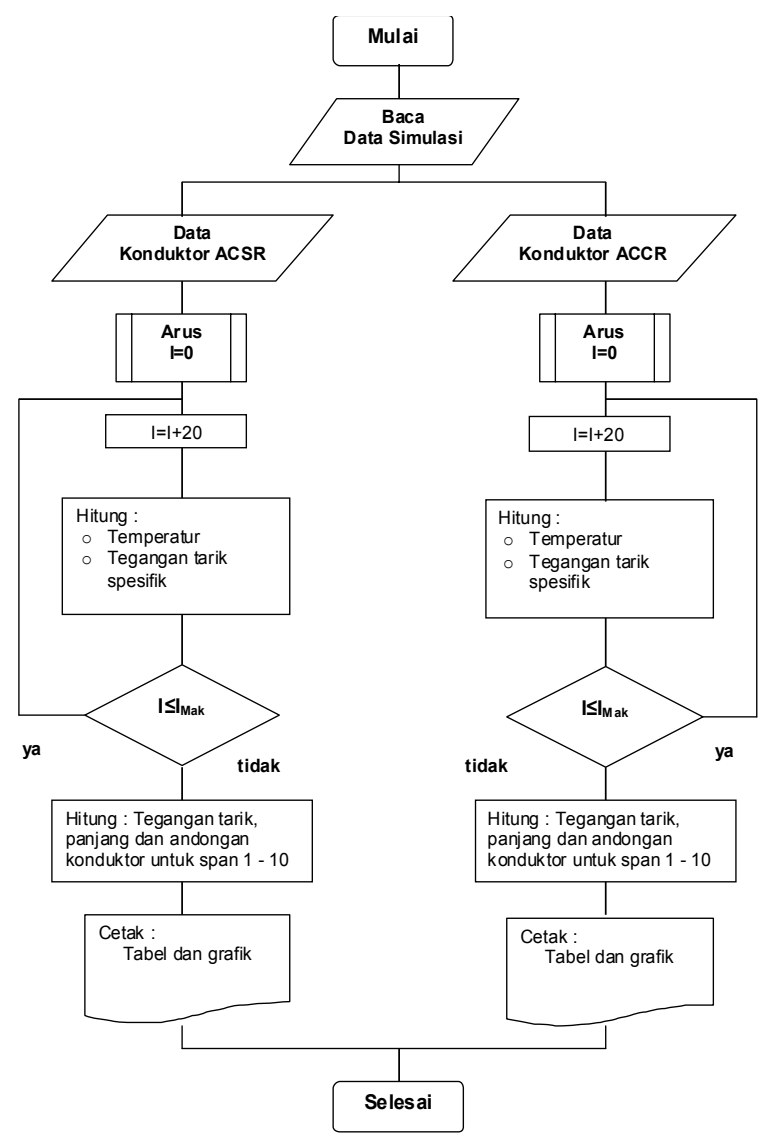

Gambar 3. Diagram Alir Program

\section{HASIL DAN PEMBAHASAN}

Penelitian dilakukan dengan menghitung besarnya temperatur, tegangan tarik, panjang dan andongan akibat perubahan arus yang mengalir pada kawat penghantar dengan menggunakan alat bantu perangkat lunak (software) Matlab.7.0 terhadap penghantar konvensional ACSR dan penghantar ACCR.
Perhitungan terhadap penghantar ACSR dengan ukuran diameter yang mendekati sama dengan penghantar ACCR juga dilakukan dengan tujuan sebagai referensi/pembanding dalam analisis. Metode yang digunakan dalam penelitian ini adalah menggunakan persamaan keseimbangan panas, untuk mendapatkan hubungan kemampuan hantar arus dengan temperatur konduktor. Sementara untuk menghitung unjuk kerja mekanis konduktor meliputi tegangan tarik, panjang konduktor dan andongan menggunakan metode Catenary dan metode Rulling span.

\section{Pengaruh Perubahan Arus Saluran Terhadap Temperatur Konduktor}

Temperatur pada kawat penghantar dipengaruhi oleh temperatur sekeliling (ambient temperature) dan rugirugi listrik. Temperatur sekeliling pada simulasi ini diambil $40^{\circ} \mathrm{C}$ dan kecepatan angin dianggap tetap sebesar $25 \mathrm{~m} /$ detik. Pada gambar 3 memperlihatkan, apabila arus konduktor bertambah akan menyebabkan kenaikan temperatur pada konduktor.

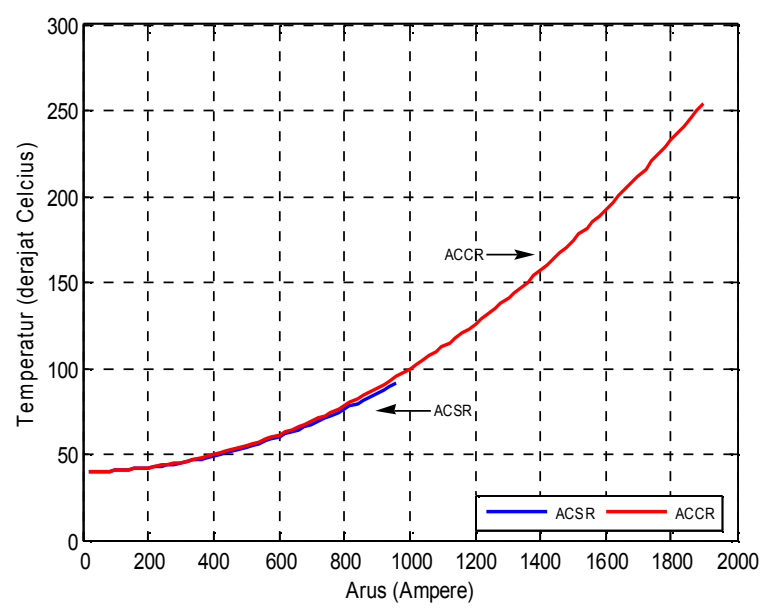

Gambar 3. Hubungan Perubahan Arus Saluran Terhadap Temperatur Konduktor

Hal ini terjadi karena arus yang mengalir dalam penghantar akan menimbulkan rugi-rugi listrik berupa energi panas yang besarnya berbanding dengan kuadrat arusnya. Dengan batas temperatur operasi maksimal pada konduktor ACCR sebesar $240^{\circ} \mathrm{C}$ dan ACSR sebesar $90^{\circ} \mathrm{C}$, maka arus maksimal yang diijinkan pada konduktor ACCR adalah 1840 ampere dan untuk konduktor ACSR adalah 940 ampere.

\section{Pengaruh Perubahan Arus Saluran Terhadap Panjang Konduktor}

Kenaikan arus saluran akan mengakibatkan kawat penghantar bertambah panjang/terjadi pemuluran sebagaimana terlihat pada gambar 4 . 


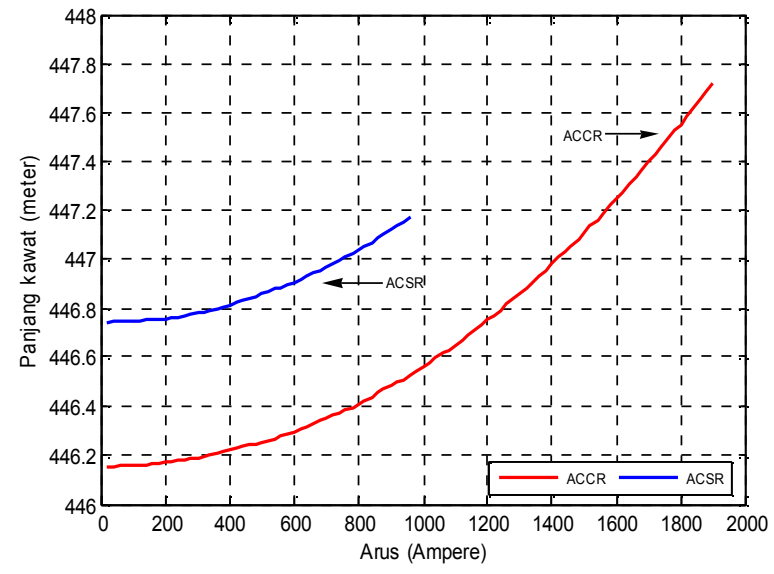

Gambar 4. Hubungan Perubahan Arus Saluran Terhadap Panjang Konduktor

Dari hasil simulasi menunjukkan bahwa konduktor ACCR mempunyai panjang kawat yang lebih pendek pada saat harga arus saluran sama, hal ini disebabkan konduktor ACCR mempunyai karakteristik tegangan tarik yang lebih besar, berat kawat yang lebih ringan dibanding konduktor ACSR sehingga dalam pemasangannya tidak memerlukan andongan yang terlalu besar dan panjang kawat konduktor menjadi lebih pendek.

\section{Pengaruh Perubahan Arus Saluran Terhadap Tegangan Tarik Konduktor}

Dengan terjadinya pemuaian/pemuluran pada konduktor akan menyebabkan regangan (strain) pada kawat penghantar turun sehingga tegangan tarik konduktor juga akan menurun.

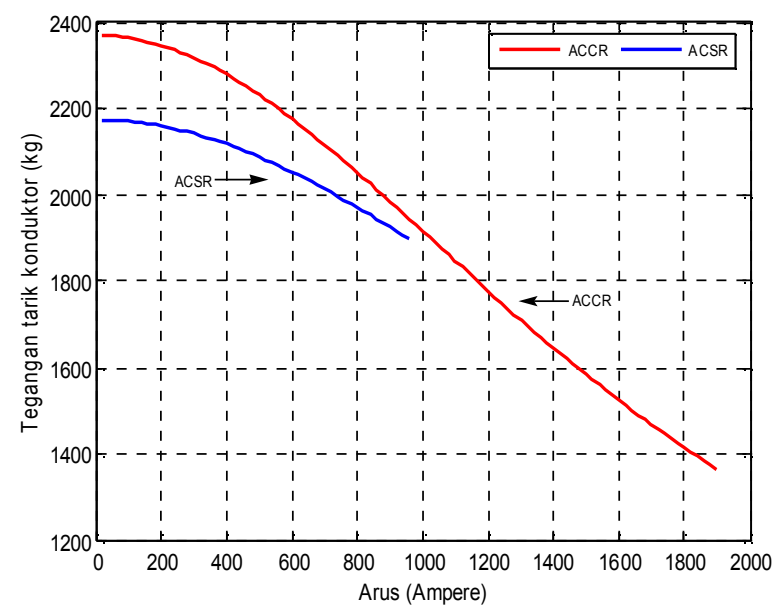

Gambar 5. Hubungan Perubahan Arus Saluran Terhadap Tegangan Tarik Konduktor

Sehingga terlihat pada gambar 5 bahwa kenaikan arus pada konduktor akan mengakibatkan menurunnya tegangan tarik konduktor. Hasil simulasi memperlihatkan bahwa pada saat harga arus saluran sama maka konduktor ACCR memiliki tegangan tarik yang lebih tinggi dari pada konduktor ACSR, hal ini disebabkan konduktor ACCR memiliki kekuatan tarik nominal lebih besar. Sesuai data karakteristik masing-masing konduktor, tegangan tarik spesifik permulaan (initial spesific tension) untuk konduktor ACCR adalah 15,22 kg/mm ${ }^{2}$ dan ACSR adalah 5,95 $\mathrm{kg} / \mathrm{mm}^{2}$

\section{Pengaruh Perubahan Arus Saluran Terhadap Andongan}

Perubahan arus saluran akan menyebabkan berubahnya andongan kawat penghantar, dengan terjadinya pemuaian/pemuluran akan mengakibatkan kawat penghantar bertambah panjang sehingga andongan akan berubah menjadi lebih besar, seperti yang ditunjukkan pada gambar 6. Jika pada kedua jenis konduktor tersebut dibebani oleh arus yang sama besar maka andongan pada konduktor ACCR lebih kecil dibanding dengan konduktor ACSR, hal ini disebabkan konduktor ACCR mempunyai karakteristik tegangan tarik yang lebih besar, berat kawat yang lebih ringan dibanding konduktor ACSR sehingga dalam pemasangannya tidak memerlukan andongan yang terlalu besar.

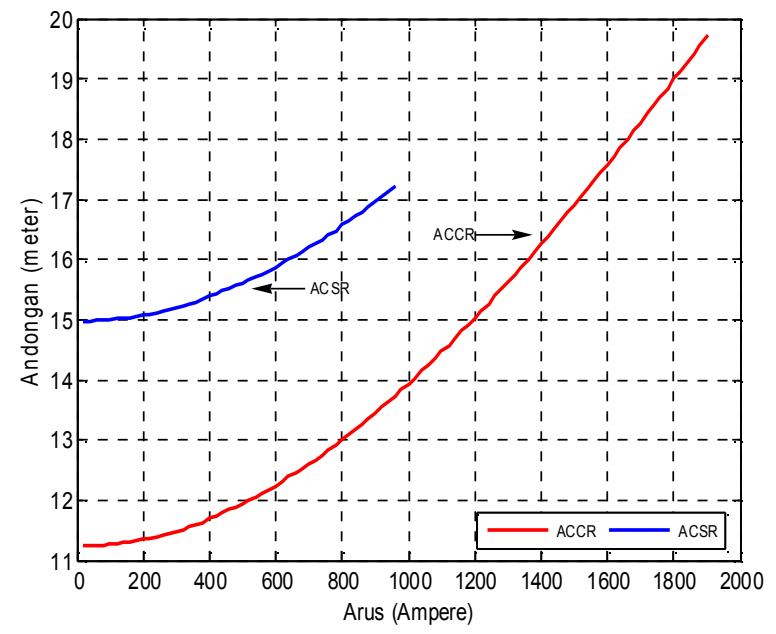

Gambar 6. Hubungan Perubahan Arus Saluran Terhadap Andongan Konduktor

Dari hasil simulasi memperlihatkan, bahwa dengan mempertimbangkan ketinggian tower, jarak bebas (clearence) dan nilai andongan maksimum dari konduktor ACSR, maka penggunaan konduktor ACCR, dapat menaikkan kapasitas hantar arus dari 780 ampere jika menggunakan konduktor ACSR menjadi 1560 ampere (kondisi pembebanan harian). Atau dapat ditingkatkan menjadi dua kali lebih besar $(100 \%)$. 


\section{KESIMPULAN DAN SARAN}

\section{Kesimpulan}

1. Kemampuan hantar arus untuk konduktor ACSR berpenampang 392,8 $\mathrm{mm}^{2}$ adalah 940 ampere pada temperatur kerja maksimum $90^{\circ} \mathrm{C}$ dan 780 ampere pada temperatur pembebanan harian $75^{\circ} \mathrm{C}$. Sementara untuk konduktor ACCR berpenampang $374 \mathrm{~mm}^{2}$ adalah 1840 ampere pada temperatur kerja maksimum $240^{\circ} \mathrm{C}$ dan 1680 ampere pada temperatur pembebanan harian $210^{\circ} \mathrm{C}$. Jadi dengan menggunakan konduktor ACCR kapasitas penyaluran pada pembebanan harian/pemakaian kontinyu dapat ditingkatkan sebesar 115,30 \%, dengan ukuran konduktor ACCR yang lebih kecil (selisih $18.77 \mathrm{~mm}^{2}$ ) dibanding konduktor ACSR.

2. Konduktor ACCR memiliki spefikasi kekuatan tarik nominal lebih besar dan berat yang lebih ringan, sehingga dalam pemasangannya memerlukan panjang kawat dan andongan yang lebih pendek dibanding konduktor ACSR.

3. Dengan mempertahankan ROW dan tower yang ada, maka penggunaan konduktor ACCR dengan ukuran penampang yang lebih kecil dibanding konduktor ACSR (selisih $18.77 \mathrm{~mm}^{2}$ ), dapat menaikkan kapasitas penyaluran sistem transmisi menjadi dua kali lebih besar (sebesar $100 \%$ ).

\section{Saran}

1. Pada penelitian ini kecepatan angin dianggap tetap, maka untuk pengembangan lebih lanjut perlu adanya penelitian yang mengamati pengaruh perubahan kecepatan angin terhadap unjuk kerja mekanis konduktor.

2. Perlu diadakan penelitian lanjutan tentang nilai ekonomis penggunaan konduktor ACCR dibanding konduktor konvensional ACSR.

\section{DAFTAR PUSTKA}

[1] William D. Stevenson Jr., Analisis Sistem Tenaga Listrik, Erlangga, Jakarta, 1990, p.38.

[2] A. S. Pabla, Sistem Distribusi Daya Listrik, Erlangga, Jakarta, 1994, p.181.

[3] 3M corporation. Conductor and Accessory Testing. Aluminum Conductor Composite Reinforced (ACCR) Technical Notebook, 2003,

[4] Prairie Business Magazine, Composite Conductor Planned for Minnesota. Staff Report. 2005.

[5] Ross, M, Clark. dan Barrett, J, S., WAPA and DOE Field Test Composite 3M Conductor, 2003.
[6] Seppa, T.O., "Accurate Ampacity Determination; Temperature-Sag Model for Operational Real-Time Rating". IEEE. Transaction on Power Delivery, V.10 No.3, 1995, pp 1460-1470

[7] Migiantoro, H.Bb. Kajian Kinerja Mekanis Konduktor ACSR dan TACSR terhadap Perubahan Arus Saluran. Tesis. Program Studi Teknik Elektro, Pasca Sarjana, UGM Yogyakarta, 2002.

[8] Jakubiak,E.A., dan Matusz,J.S. "High Temperature Tests of ACSR conductor Hardware", IEEE Transactions on Power Delivery. Vol.4. No.1, 1989

[9] Dauglass, D.A., Motlis,Y. dan Seppa,T.O. IEEE'S Approach For Increasing Transmission Line Ratings in North America, .2003

[10] IEEE Std. 738, Standard for Calculating the Current-Temperature Relationship of Bare Overhead Conductors, IEEE Power Engineering Society, 1993.

[11] T.S.Hutauruk, Transmisi Daya Listrik, Erlangga, Jakarta, 1999, p.152.

[12] Thayer, E.S.1924. Computing Tension in Transmission Line, Electrical World Magazine, p. 72-73.

[13] PT. PLN, Lot 1: Paiton - Kediri, Vol. 3, 500kV Transmission Lines Paiton-Kediri-Klaten Projects, 1997. 